\title{
Mentoring for Catholic school leadership
}

Formation of 'Servant Leaders' in the schools of the Sisters of St Paul of Chartres in Thailand

\section{Kaetkaew Punnachet, Boonraksa Sritrakul and Atchara Supavai}

\section{Introduction}

This chapter aims to discuss the idea of the importance of 'mentoring' to form 'Servant Leaders' in Thai Catholic schools by focusing on transmitting a distinctive value system and ethos. It should be noted at the beginning of this chapter that it is a synthesis of three doctoral research theses supervised by Professor Gerald Grace. All three developed the research ideas from the writings of Gerald Grace (Grace, 1995, 2002). This chapter is divided into five major parts. The first part briefly explores concepts of Catholic schools based on Grace's research and writings $(1995,2002)$. The second part gives a brief introduction to the background of this chapter. The third part examines the important concept of mentoring the values of Catholic Servant Leadership. The fourth part provides a case study, focusing on mentoring in Catholic formation programmes in Sisters of Saint Paul of Chartres schools in Thailand. It will be concluded that the mentoring scheme described in this chapter, designed to form future leaders in the charism of the Congregation, is one that other schools could emulate.

\section{Grace's concepts of Catholic schools and Catholic school leadership}

For Grace (1995, 2000, 2002), Catholic schools are culturally and morally distinctive as educational institutions. Consequently, it is necessary to investigate other 'educational characteristics' such as passion, love, humility, etc. From his research it can be concluded that the Catholic school system has its own unique attributes, different from those of other state schools. Above all, at their best, they are focused on the life and teachings of Jesus Christ according to Catholic tradition.

Catholic school leaders should be distinctive, i.e.: being professionals and 'being witnesses'. Grace (2002) strongly proposed that there should be two 
major dimensions of Catholic school leadership: 'professional in leading' and 'professional as witness'.

Sritrakul (2013) elaborated the term 'The professional in leading', which could be perceived as the leader who exercises 'secular' leadership style without any attention to religious values. 'Professional as witness' (Grace, 2002, and Duncan, 1990, in Sritrakul, 2011) implied that the character of a principal and the need to articulate Catholic identities and to create a Catholic educational environment as part of the Christian culture of a school were essential elements.

The concept of the 'professional' as 'witness' is most powerful for Catholic educators. Above all else, the Gospel must be proclaimed by witnesses. ${ }^{1}$ The most influential resource is Christ, who practises what He preaches (Sritrakul, 2011). Also, Grace strongly argues that any study of school leadership must start with an understanding of the historical and cultural context (Grace, 1995) in which leadership is developed.

\section{Background of this chapter}

It was the work of Grace (1995) about how Catholic school leaders should consider the cultural and organisational context that inspired Punnachet's work (2006) on the idea of Catholic Servant Leadership in Catholic schools in Thailand. The research was conducted in eight large schools of the Sisters of Saint Paul of Chartres, which have between 2,000 and 5,000 students. Data were collected by shadowing, through personal interviews and also through the distribution of questionnaires. Her research confirms Grace (1995) and Day et al. (2007), who argue for the need for a distinction between educational leadership and corporate leadership and especially for Catholic school leadership and its values.

Moreover, Supavai (2010) conducted research based on Grace (1995) and Punnachet (2006) on moral and spiritual values. Her research also confirmed that it is necessary to understand the unique values of Catholic school leadership (Grace, 1995, 2000, and 2002). The research found that charity, simplicity, regularity and work as vocation are the four major values that inform SPC leadership styles. Moreover, the research revealed that moral and spiritual values clearly influenced the principals' behaviours.

Furthermore, Sritrakul (2013) based on Supavai (2010) and Punnachet (2006) focused her research on 'systematic leadership succession planning' in the schools of the Sisters of St Paul of Chartres (SPC) Religious Congregation in Thailand. She concluded and provided systematic recommendations on future leadership programmes, which need to include: (a) a systematic programme of mentoring (in theory and practice), (b) an emphasis upon the importance of 'mission integrity' and of the concepts of 'servant leadership' and (c) the development of 'discernment capacity' ${ }^{2}$ in those preparing for leadership. It also demonstrated that Catholic values and the values of the culture of Thailand have to be carefully appreciated. 


\section{Sisters of Saint Paul of Chartres: Research site and context}

As all three studies were conducted in Sisters of Saint Paul of Chartres schools, it will be useful to provide some information about this Religious Congregation in order to have a more in-depth understanding of the context of this study.

Saint Paul of Chartres schools are run by the Sisters of the Congregation of Saint Paul of Chartres, which was founded in 1696 in a small village in France, called Levesville la Chenard, to teach children and to care for the sick: at the time, this care was provided in the patients' homes.

The Congregation is a religious institute of pontifical right dedicated to the apostolate in the Catholic Church. Its members dedicate themselves to education and to the care of the sick and the underprivileged. Thus, they try to be available for all forms of activities within these fields. The mission to spread this work abroad is within the purpose of 'going to those places where they are wanted' (Book of Life: 1988, p. 12). Their primary work was to educate young girls and to visit and care for the poor and sick. With their commitment and hard work, their work expanded.

The charisms of the Sisters of Saint Paul of Chartres are teaching and nursing. They work in 34 countries, in six continents. There are more than 4,400 Sisters worldwide in missions in 34 countries such as Thailand, Hong Kong, Japan, Australia, the Philippines, Madagascar and Central Africa. Sisters of Saint Paul of Chartres have been working in Thailand for more than 120 years. At present, there are 33 schools in 20 provinces under their responsibility around Thailand. There are 3,313 teachers and 67,953 students in these schools (Punnachet and Supavai, 2007).

All three studies in Catholic schools in Thailand have been influenced by the work of Grace $(1995,2002)$, who argued:

It is necessary therefore for educational leaders to demonstrate some understanding of moral complexity and some capacity for making explicit the relationships between values and proposed actions in educational institutions.

(Grace, 1995, p. 63)

Supavai (2010) raises another challenging issue about 'faith and values formation' in contemporary culture, since there are fewer members of Religious Orders to work in the schools. This means that students do not see as many visible 'professionals as witnesses' as they did in the past. At their best, Religious Sisters and Brothers in schools are 'the faith made manifest'.

In short, this section provides a broad picture of the background of this chapter. We would like to use Grace's statement to conclude this section.

The Catholic school system internationally has benefited from the presence of significant spiritual capital among its school leaders... is that spiritual 
capital of leadership being reconstituted in new ways, or is it being depleted? If the latter is the case, then the mission integrity of Catholic schooling in the future could become much more problematic.

(Grace, 2002, p. 447)

\section{Mentoring: Transmitting values of Catholic servant leadership}

The above does raise the question of how to form Catholic servant leaders in Catholic schools since Catholic schools need a unique leadership. Sritrakul (2013) stressed that today leadership theory has been adopted from business and corporate models which are rooted in fields such as industrial psychology, management literature, political science and social science. The humanities, which include philosophy and ethical dimensions, seem to have been neglected in many leadership theories (Crow and Grogan, 2003, p. 362). The neglect of the humanities in the development of leadership theory is affirmed by Grace (1995), Hodgkinson (1991) and Greenfield (1993), who argued that educational administration is not only a science, but is based predominantly on philosophy and values. This problem seems to be more serious for education, especially when the leaders are in a Catholic environment (Punnachet, 2006).

Grace (1995) reminds us that when borrowing concepts from corporate leadership to use in an educational context, the dangers of losing the sense of 'educational leadership' need to be kept in mind. Grace argued that the adoption of the culture of corporate leadership could critically undermine the work of educational leaders. He further argued that when neglecting the values context of educational settings, educational leaders could merely become 'chief executives, market analysts and public relations specialists' (Grace, 1995, p, 5). This was a potential danger, especially in large secondary schools.

Applying this to the context of religious-run Catholic schools in Thailand, Punnachet (2006) argued that Jesus must be the centre of leadership practice. The 'Spirit to serve' is considered as a crucial factor in the leadership of Catholic schools.

However, Punnachet (2006) suggested that leadership programmes must be transformed from 'training' to 'educating'. This corresponds with Southworth (1995), who pointed out that leadership 'training' has been overwhelmed by management courses preoccupied with technical matters (p. 204). He further argued that management courses often ignore ethical issues and personal values and beliefs.

Supavai (2010) raised an important issue. She said that it is necessary to understand the unique values of Catholic school leadership, as many researchers such as Grace (1995, 2000, and 2002; Bryk et al., 1993) have demonstrated in their studies. In her research on value systems, she found that charity and fidelity are very distinctive, as shown in the interviews. 'Simplicity' seems to be the neglected value. The researcher urged that 'fidelity' should be considered more by SPC members, as it will provide a more distinctive characteristic to SPC schools. 
As far as the definition of this value (i.e. fidelity) is concerned, it means to be loyal to the rules of the Congregation and loyal to the teachings of Christ and the Church. It is the most important value for the members themselves. Additionally, 'simplicity' is also an important value, as the Congregation started in a simple way, as a service to the poor. This aspect of mission integrity has weakened over time. The Sisters are now less in the service of the poor than they were at the beginning of the mission. ${ }^{3}$

However, her research found a tendency of the principals to become preoccupied with management issues to the detriment of values-led educational leadership and a reduced impact of the values of the principal on the whole school culture, arising partly from the increasing size of the schools. Grace raised a major question to consider, which focused on Catholic values and market values. He clearly argued that:

...the critical question for Catholic school leaders in new circumstances is 'can a balance be found between Catholic values and market values, or will market forces begin to compromise the integrity of the special mission of Catholic schooling? Can Gospel values survive in the face of a more direct relationship with the market place?'

(Grace, 1995, p. 84)

It is important to consider how values are the motivating factors for behaviour, and that values underpin effective leadership and lead to effective schools (Supavai, 2010).

Sritrakul (2013) maintained that mentoring seems to be the most suitable method for forming Catholic educational leaders. To her, mentoring occurs between two persons or two groups. The first is the mentor and the second is sometimes called the protége or mentee. The purpose of mentoring is to assist mentees in the early years of their work. Basically, mentoring is about assisting change by providing support. Through communication with a mentor, mentees can explain their thoughts and obtain feedback in order to transform their behaviour. There are also some crucial elements whose influence on mentoring must be considered: the qualities, skills and virtues of mentors need to be examined.

Sritrakul explained how Plamondon (2007, p. 6) concludes that 'The concept of a good mentor as founded in essential qualities can be extended to an integrated conceptual model for competence to mentor'. In his model, 'a good mentor demonstrates a balance of virtues, abilities and competencies essential for achieving and maintaining competence to mentor'.

Virtues need to be stressed here. Plamondon (2007, p. 8) explained that:

Mentor virtues of integrity, caring and prudence are described as the foundation to competence. Integrity reflects the ability to establish and maintain trust in a mentoring relationship, drawing from the presence of 
honesty and mutuality. Caring as a virtue means that the mentor demonstrates respect and empathy to others-both within and outside of the mentoring relationship. Prudence indicates the intentionality and appropriateness of the mentor as demonstrated through decision making.

\section{Mentoring: The way to form value systems for Catholic educational leaders}

Although mentoring has been used since the Sisters of St. Paul began work in Thailand, through the spirit and values of the Congregation, they have been increasing their schools' effectiveness. It should be noted here that the technique of mentoring is always employed in religious life, as Sisters live their lives fraternally. This is a life which, at its best, 'calls for sympathetic sharing of joys and sorrows, cares and difficulties, work and apostolate, with understanding and tact'. The most important concern is that mentoring serves as an internal promotion. This is the process of choosing internal candidates for principalship. Thus, the most suitable process is more likely to involve pre-service development and mentoring. However, in Thailand there remains an urgent need to frame more systematic preparation for future principals in order to have 'Catholic Values' in the leadership.

\section{Real implementation of mentoring in 2014-2017}

It should be noted that after Sritrakul (2013) proposed her thesis to the Congregation Committee, her 'Experimental Project for Mentoring Programme' (Sritrakul, 2013) has been approved and brought to real implementation. The Congregation approved the mentoring project in order the provide help or enable mentors to continue to work with the candidates, especially in their early years in the role. As there is not much time to accumulate experiences, the mentoring technique seems to be a useful way to 'grow leaders over time'.

The experimental team did the following:

1 Choose three mentors from experienced principals and between three and six mentees from aspirants who are willing to participate in the programme.

2 Explained the duties and responsibilities for mentors in helping their mentees. ${ }^{5}$ For the best outcome, mentors should act to the best of their ability within plain sight of their mentees and both parties should engage in a compassionate and mutual search for wisdom (Bell, 1996). ${ }^{6}$

3 Each principal formed a team (which will be called a mentor team) at their schools, by selecting experienced teachers to act as mentors for mentees who will be assigned to develop their experiences in a variety of roles that future principals should be familiar with. The reason why principals should form a team is because 'the fact that a principal is experienced and successful is no guarantee that he or she will be a good mentor.' Moreover, 
teachers are the ones who are still working in this area and know it better than anyone else. As Leithwood et al. ${ }^{8}$ argue:

A great many factors in a leader's environment shape his or her actual practices - educational policies, on-the-job leadership opportunities, mentoring experiences and professional development initiatives, for example. But the actual effects of all these external experiences on leaders' practices are mediated by their inner lives - their thoughts, feelings, educational histories, professional identities, values and dispositions. According to this account, attributions of leadership emerge from two distinctly different mechanisms resemblance to individual leader prototypes (recognition-based attributions) and direct experiences with the potential leader (inference-based attributions). (2006, p. 68)

In this context, members of the mentor team are skilled religious principals and skilled teachers in school who will provide technical assistance and collect information from participants to help them develop as leaders.

Pair the mentor and mentee by letting the mentee choose her mentor. This served to improve mentees' self-confidence, as they are younger, and will help to ensure that the programme will succeed by making appropriate matches (Cordeiro and Smith-Sloan, 1995). ${ }^{9}$

Prepared topics for mentees to learn from the mentor team and the mentor. Mentees should observe and work with mentor teams under the topics given. Every two months, they should report what they have learned, any problems they have encountered, any questions that have arisen and any suggestions that they wish to make. They will also receive feedback from the team on areas of strength and weakness.

Areas in which mentees had been prepared are as follows:

Table 18.I An outline of the areas in which mentees had been prepared

\begin{tabular}{|c|c|c|c|c|}
\hline & Area & Objective and result & Formator & Cycle \\
\hline 1 & Ethnography & $\begin{array}{l}\text { Candidates learnt about the culture of } \\
\text { the school, which is essential knowledge } \\
\text { for a school leader. } \\
\text { First and foremost, they learnt about } \\
\text { the characteristics of Catholic schools } \\
\text { and their Catholic identities. } \\
\text { The area of study is based on the view } \\
\text { that an effective principal must know } \\
\text { about the culture of the place in which } \\
\text { she will work and the local society's } \\
\text { requirements (from the local authority } \\
\text { and the traditions of each area). }\end{array}$ & $\begin{array}{l}\text { Principal } \\
\text { Principal } \\
\text { Mentor } \\
\text { team }\end{array}$ & $\begin{array}{l}1 \\
1 \\
1\end{array}$ \\
\hline
\end{tabular}


Table 18.1 (Cont.)

\begin{tabular}{|c|c|c|c|c|}
\hline & Area & Objective and result & Formator & Cycle \\
\hline 2 & $\begin{array}{l}\text { Leadership and } \\
\text { management }\end{array}$ & $\begin{array}{l}\text { Mentoring programmes had adminis- } \\
\text { trative support, adequate funding and clear } \\
\text { leadership (Exworthy and Halford, 1999). } \\
\text { Thus, candidates examined how leader- } \\
\text { ship is practised, its moral and ethical } \\
\text { aspects, and the interaction between } \\
\text { leading and being led. }{ }^{10}\end{array}$ & $\begin{array}{l}\text { Principal } \\
\text { Principal }\end{array}$ & 1 \\
\hline 3 & $\begin{array}{l}\text { Morals and } \\
\text { ethics for how } \\
\text { students form } \\
\text { conscience for } \\
\text { faithful } \\
\text { citizenship }\end{array}$ & $\begin{array}{l}\text { They knew about the school regulations } \\
\text { and should have the ability to be flexible } \\
\text { according to their conscience. }\end{array}$ & Principal & 2 \\
\hline 4 & $\begin{array}{l}\text { Evaluation, } \\
\text { assessment and } \\
\text { organisational } \\
\text { learning }\end{array}$ & $\begin{array}{l}\text { They learnt about the SPC Educational } \\
\text { Board and state assessment and } \\
\text { accountability programmes. }\end{array}$ & $\begin{array}{l}\text { Mentor } \\
\text { team }\end{array}$ & 2 \\
\hline 5 & $\begin{array}{l}\text { Staff } \\
\text { development }\end{array}$ & $\begin{array}{l}\text { They learnt to understand the char- } \\
\text { acteristic of staff's work in order to } \\
\text { understand the content of teachers' } \\
\text { tasks. This is to avoid staff overload. }\end{array}$ & $\begin{array}{l}\text { Mentor } \\
\text { team }\end{array}$ & 3 \\
\hline 6 & $\begin{array}{l}\text { Curriculum, } \\
\text { teaching, lesson } \\
\text { planning and } \\
\text { evaluation }\end{array}$ & $\begin{array}{l}\text { They know about the curriculum, tea- } \\
\text { chers' lesson planning and students' } \\
\text { evaluation. }\end{array}$ & $\begin{array}{l}\text { Mentor } \\
\text { team }\end{array}$ & 3 \\
\hline 7 & $\begin{array}{l}\text { Ecumenical } \\
\text { education }\end{array}$ & $\begin{array}{l}\text { As they work in a strong Buddhist coun- } \\
\text { try, they should respect the culture of } \\
\text { other religions, including Islam. }\end{array}$ & Principal & 4 \\
\hline 8 & $\begin{array}{l}\text { Principal's } \\
\text { responsibility }\end{array}$ & $\begin{array}{l}\text { They understood duty of choosing stu- } \\
\text { dents to study, especially the poor and } \\
\text { marginalized. }\end{array}$ & Principal & 4 \\
\hline 9 & $\begin{array}{l}\text { Identity of } \\
\text { Catholic } \\
\text { schools, and } \\
\text { mission } \\
\text { integrity }\end{array}$ & $\begin{array}{l}\text { They knew the identity }{ }^{11} \text { of the Catholic } \\
\text { school as rooted in Gospel values. } \\
\text { They should know and promote the } \\
\text { importance of 'mission integrity', the } \\
\text { service to the poor; the spirit of servant } \\
\text { leadership, to reduce the gap of the } \\
\text { power distance dimension of Thai cul- } \\
\text { ture and Catholic culture. } \\
\text { Promote the passion for and commitment } \\
\text { to 'New Evangelisation'. Presenting the } \\
\text { faith in new ways, for modern youth. }\end{array}$ & $\begin{array}{l}\text { Experienced } \\
\text { Principals }\end{array}$ & $\begin{array}{l}\text { At the } \\
\text { end of } \\
\text { each } \\
\text { school } \\
\text { term. }\end{array}$ \\
\hline 10 & $\begin{array}{l}\text { 'Discernment': } \\
\text { applying spiri- } \\
\text { tual reflections } \\
\text { to decision- } \\
\text { making }\end{array}$ & $\begin{array}{l}\text { They are aware of the importance of } \\
\text { how to discern in their decision-making. } \\
\text { There should be time to participate in } \\
\text { seminars on discernment development, } \\
\text { and prayer sessions on policy issues. }\end{array}$ & $\begin{array}{l}\text { Principals } \\
\text { and } \\
\text { Authority } \\
\text { from SPC } \\
\text { Board }\end{array}$ & $\begin{array}{l}\text { At the } \\
\text { end of } \\
\text { each } \\
\text { school } \\
\text { term. }\end{array}$ \\
\hline
\end{tabular}




\section{Conclusion}

We believe that all Religious Congregations with their missions in education will benefit from adopting a mentoring process similar to this. For all Catholic schools which are diocesan foundations, we believe that mentoring processes for future leadership, by 'growing your own leaders', should be developed. In-school programmes in Catholic schools can form Catholic religious and lay aspirants in spiritual values as well as professional competencies and organisational skills. The great Catholic model, based on the example of Jesus Christ himself, of 'Servant Leadership' can serve as an ideal to be attempted (although difficult to attain) when contemporary secular models seem to favour models of Executive and Corporate leadership in education.

We offer, from Thailand, one example of how this can be done. This chapter is provided for the glory of God, for the good of the Church and for the service of all Catholic educators across the world.

\section{Notes}

1 Pope Paul VI, Evangelii Nuntiandi (1976).

2 Discernment needs time and prayer. A retreat or a period of time for principals to revisit their own behaviour could provide more insightful understanding of their own self-awareness and their self-improvement. Perhaps a programme of personal and group retreats with a focus on leadership could be introduced for the Sisterprincipals. The Sisters could suspend their work for days or weeks to reflect on their leadership roles and relationship with God and on the mission of Catholic education. Personal retreats would need to be done before and after these group retreats, to give each principal the opportunity to reflect on her behaviour. The Sisters would therefore have the opportunity to share their experiences and how they deal with situations openly. They could consequently find ways to practise more Catholic-based educational leadership (Punnachet, 2006).

3 The Congregation is working in many cities and with the hill tribe people, providing quality education to them. In some schools, the Sisters provide all free education for the poor and underprivileged students. Please see Punnachet and Supavai (2007).

4 Book of Life, no. 39.

5 High-quality formation for mentors also prepares them to provide and receive feedback that encourages self-reflection, is not judgemental, does not simply provide a new principal with 'war stories' or 'right answers', and aims at moving new principals from dependence to independence (Wallace and Gravells, 2007).

6 Bell (1996).

7 Wallace and Gravells (2007).

8 Leithwood et al. (2006).

9 Cordeiro and Smith-Sloan (1995).

10 Huber (2004, p. 284).

11 Burke (2000, p. 225, based on Stryker, 1980) argues that in identity theory 'selfcategorization is equally relevant to the formation of one's identity, in which categorisation depends upon a named and classified world'. The mentees should be aware of these to understand and fulfil Catholic identity as part of their mission integrity, i.e. to live the mission and not only write it in school mission statements. 


\section{References}

Bell, C.R. (1996). Managers as Mentors: Building Partnerships for Learning. San Francisco: Berrett-Koehler Publishers, Inc.

Byrk, A., Lee, V. and Holland, P. (1993). Catholic Schools and the Common Good, Cambridge, MA: Harvard University Press.

Burke, J. P. (2000). Identity theory and social identity theory, Social Psychology Quarterly, 63: 3, pp. 224-237.

Cordeiro, P.A. and Smith-Sloan, E. (1995). Apprenticeships for Administrative Interns: Learning to Talk Like a Principal. Paper Presented at the Annual Meeting of the American Educational Research Association. San Francisco, 18-22 April 1995.

Crow, G.M. and Grogan, M. (2003). Mentoring in educational leadership for organizational transformation. In Clutterbuck, D.A., Kochan, F. K., Lunsford, L., Dominguez, N. and Haddock-Millar, J. (Eds.), The Sage Handbook of Mentoring. New York: SAGE Publications Ltd., pp. 436-450.

Day, C., Sammons, P., Harris, A., Hopkins, D., Leithwood, K., Gu, Q., Penlington, C., Mehta, P. and Kington, A. (2007). The Impact of School Leadership on Pupil Outcomes, DfES Interim Report (Year 1). London: Department for Children, Schools and Families.

Exworthy, M. and Halford, S. (2000). Professionals and new managerialism in the public sector. Social Science \& Medicine, 51. doi:10.1016/S0277-9536

Grace, G. (1995). School Leadership: Beyond Educational Management. London: Falmer Press.

Grace, G. (2000). Research and the challenges of contemporary school leadership: The contribution of critical scholarship. British Journal of Educational Studies, 48: 3, pp. 231-247.

Grace, G. (2002). Mission integrity. In Leithwood, K. and Hallinger, P. (Eds.), Second International Handbook of Educational Leadership and Administration, Part 1 Chapter 13. Dordrecht, Netherlands: Kluwer Academic Press, pp. 427-449.

Grace, G. (2002). Catholic Schools: Mission, Markets and Morality, London and New York: Routledge Falmer.

Greenfield, T.B. (1993). The man who comes back through the door in the wall: Discovering truth, discovering self, discovering organizations. In Greenfield, T. and Ribbing, P. (Eds.), Greenfield on Educational Administration: Towards a Humane Science. London: Routledge, pp. 92-119.

Greenfield, W. (1995). Toward a theory of school administration: The centrality of leadership. Educational Administration Quarterly, 31: 1, pp. 61-85.

Hodgkinson, C. (1991). Educational Leadership: The Moral Art. Albany, NY: State University of New York Press.

Huber, S. (2004). School leadership and leadership development: Adjusting leadership theories and development programs to values and the core purpose of school. Journal of Educational Administration, 42, pp. 669-684.

Leithwood, K., Day, C., Sammons, P., Harris, A., and Hopkins, D. (2006). Seven Strong Claims about Successful School Leadership. Nottingham: NCSL Publications.

Plamondon, K. and CCGHR. (2007). Capacity Building Task Group: available online at: www.inclentrust.org/uploadedbyfck/file/compile\%20resourse/new-resourse-dr_-vishal/ Mentoring_Module2_e.pdf.

Punnachet, K. (2006). Catholic Servant Leadership in Sisters of Saint Paul of Chartres Schools in Thailand. Unpublished PhD Thesis, Institute of Education, University of London. 
Punnachet, K. and Supavai, A. (2007). Challenges for the schools of the Sisters of Saint Paul of Chartres in Thailand. In G. Grace and J. O'Keefe (Eds.), International Handbook of Catholic Education: Challenges for School Systems in the 21st Century. Heidelberg: Springer, pp. 737-748.

Southworth, G. (1995). Looking into Primary Headship: A Research Based Interpretation. London: Routledge.

Sritrakul, B. (2013). The Preparation for Succession Planning for Future SPC Principals in Thailand. Unpublished Doctor of Education Thesis, Educational Leadership, School of Education, University of Nottingham.

Stryker, S. (1980). Symbolic Interactionism: A Social Structural Version. Menlo Park: Benjamin Cummings.

Supavai, A. (2010). SPC Principals' Perceptions of and Practices in Relation to Spiritual and Moral Values in SPC Catholic Schools in Thailand: The Challenge of Change. Doctor of Education Thesis, Educational Leadership, School of Education, University of Nottingham.

Wallace, S. and Gravells, J. (2007). Mentoring, 2nd ed. Exeter: Learning Matters. 